\title{
FEIRA DO ROLO NA PEDAGOGIA DA MALANDRAGEM: memória e representações sociais no espaço urbano de Ceilândia-DF
}

\section{Breitner Luiz Tavares}

Curso: Mestrado em Sociologia

Data de defesa da dissertação: 28 de fevereiro de 2005

Orientadora: $\operatorname{Prof}^{\mathrm{a}} \mathrm{Dr}^{\mathrm{a}}$ Bárbara Freitag Rouaet

\section{Resumo}

A Feira do Rolo constitui um mercado que, em relação a outros centros comercias, oferece ao consumidor produtos diversos a preços acessíveis. O que diferencia esta feira das demais é a prática do "rolo" - sistema de trocas informais.

A prática do "rolo" acompanha a história da Ceilândia - cidadesatélite localizada a $25 \mathrm{~km}$ de Brasília - desde seu surgimento. Portanto, é parte da memória coletiva da cidade, uma alternativa no mercado de trabalho informal. Nesse contexto verifica-se uma situação de conflito: de um lado, a polícia e o Estado efetuam fiscalização em defesa da "ordem"; de outro, há uma comunidade que reivindica o status de legitimidade para a prática do "rolo" mesmo que este esteja associado à imagem da contravenção ou a comportamentos típicos do universo da malandragem.

Esta dissertação configura um estudo de caso, uma pesquisa de cunho qualitativo que visa reconhecer na Feira do Rolo a segregação socioespacial presente em Brasília visto que há, em sua dinâmica de funcionamento, representações sociais do cotidiano da cidade na qual está inserida. 
Como recurso metodológico, usou-se a análise do discurso de atores sociais como: feirantes, moradores, autoridades locais, entre outros, com o intuito de perceber se este é um espaço eminente da contravenção ou se o "rolo" constitui um referencial significativo para a memória coletiva de seus participantes.

Palavras-chave: sociologia urbana, sociologia da cultura, metropolização, periferização, Brasília, Ceilândia, representação social, malandragem, memória, patrimônio imaterial. 